\title{
Phytoremediation Potential of Iris spp.
}

\author{
Ioana CRIȘAN ${ }^{1 *}$, Roxana VIDICAN ${ }^{1}$, Anca PLEȘA1 ${ }^{\text {, Tania MIHĂIESCU }}{ }^{1}$ \\ ${ }^{1}$ Faculty of Agriculture, University of Agricultural Sciences and Veterinary Medicine of Cluj-Napoca, \\ Calea Mănăștur 3-5, Cluj-Napoca, 400372, Romania \\ * Corresponding author: I. Crișan e-mail: crisan.ioana@outlook.com
}

\section{REVIEW}

\begin{abstract}
Iris plants are widely cultivated flowering ornamentals, with a long history of traditional use in Eurasia, where this genus is reaching the highest diversity. This paper aims to provide an overview on recent advances related to the phytoremediation potential of plants from the genus Iris, in order to promote the use of these species in phytoremediation programs. According to the relevant literature, eight species from genus Iris present phytoremediation potential (I. dichotoma, I. germanica, I. halophila, I. lactea, I. latifolia, I. pseudacorus, I. sibirica, I. wilsonii). The studies addressed potential of plants to mitigate toxic metals/metalloids $(\mathrm{As}, \mathrm{Cd}, \mathrm{Cr}, \mathrm{Cu}, \mathrm{Fe}, \mathrm{Hg}$, $\mathrm{Mn}, \mathrm{Ni}, \mathrm{Pb}, \mathrm{Zn}$ ), excess of nutrients $(\mathrm{P}, \mathrm{N})$, pesticides, petroleum hydrocarbons, pharmaceuticals as well as dyes. Most studies focused on wastewater treatment and environments contaminated due to mining activities. Main hindrances in upscaling this green technology remain mitigation of toxicity stress in plants during remediation and the disposal of resulting contaminated biomass. In this sense, use of beneficial microorganisms to alleviate phytotoxicity effects and new valorization possibilities of contaminated Iris spp. biomass have been proposed recently. Designing an entire cycle that includes phytoremediation and sustainable value chains for contaminated biomass could prove feasible and should receive more attention.
\end{abstract}

Keywords: pollutant; phytoextraction; macrophyte; geophyte.

Received: 23 October 2020

Accepted: 28 April 2021

Published: 15 May 2021

DOI:

10.15835/buasvmcn-agr:2020.0046

(C) $\odot \Theta \Theta(\odot) 2021$ Authors. The papers published in this journal are licensed under the Creative Commons Attribution-NonCommercialNoDerivatives 4.0 International License

\section{INTRODUCTION}

Pollution is one of the greatest environmental concerns worldwide today (Rai et al., 2020; Surriya et al., 2015). According to European Environmental Agency, management of contaminated land costs about 6.5 billion EUR/year in Europe alone (EEA, 2020). Phytoremediation is a process that relies on plants to mitigate various pollutants from the environment (Zhang et al., 2020; Tiwari et al., 2019), enjoys a better public acceptance than other remediation methods (Suman et al., 2018) while also involving lower costs (Surriya et al., 2015). Based on the underlying process, the phytoremediation technology has been subdivided in the following categories: phytoextraction, rhizofiltration, phytostabilisation, phytovolatilization, phytodegradation (Ali et al., 2013; Jabeen et al., 2009), (Table 1). It is well known that not all plants can be used for phytoremediation. Also, plants suitable for phytoremediation are not equally efficient at performing all these processes (Ansari et al., 2017). Due to this, screening the literature for the optimal assortment of plant species based on environmental conditions and substrate type, desired effects, depth of contamination as well as pollutants targeted for decontamination is always the most important step when planning phytoremediation.Through phytoextraction plants take the contaminants through roots and then store them into aboveground organs (Pajević et al., 2016). 
Thus, repeated disposal of biomass speeds up the remediation process (Jabeen et al., 2009). Rhizofiltration ensures sequestration or precipitation of contaminants at the level of underground plant parts and the species with fibrous and higher root surface are most suitable for this process. Phytostabilisation makes use of root sorption and chemical fixation processes to prevent vertical migration of the pollutants. This is merely an immobilization of pollutants which are not removed.This process can be boosted by ensuring a higher organic content of soil through application of amendments (Clemente et al., 2019; Jabeen et al., 2009). Rhizosphere environment through root exudates and microbial activity becomes enriched with various organic substances such as organic acids, carbohydrates, amino acids, lipids, and various aromatics that contribute to the stabilization of the polluting agents (Barbosa and Fernando, 2018). Through phytovolatilization the contaminants are taken up by the plant and then converted into gaseous forms that are then released in the ambient air through stems and leaves (Limmer and Burken, 2016). As it is the case for $\mathrm{Hg}$ and Se, these are released from the plant having lesser toxic forms: gaseous elemental mercury and dimethyl selenide (Jabeen et al., 2009). Phytodegradation takes place with the help of rhizosphere plant-microorganism associations (Chlebek and Hupert-Kocurek, 2019), as well as through enzymes released into the soil by the plants such as dehalogenase, laccase, nitroreductase, peroxidase and nitrilase (Jabeen et al., 2009).

Table 1. General classification and suitability of various phytoremediation types

\begin{tabular}{|c|c|c|c|c|c|}
\hline $\begin{array}{c}\text { Phytoremediation } \\
\text { type }\end{array}$ & $\begin{array}{c}\text { Removing } \\
\text { pollutants } \dagger\end{array}$ & $\begin{array}{l}\text { Biomass } \\
\text { disposal }\end{array}$ & $\begin{array}{l}\text { Optimal } \\
\text { substrate } \ddagger\end{array}$ & $\begin{array}{c}\text { Pollutants } \\
\text { remediated }\end{array}$ & Sources \\
\hline phytoextraction & + & + & S, W & $\mathrm{Pb}, \mathrm{Cd}, \mathrm{Ni}, \mathrm{Cu}, \mathrm{Cr}$ & $\begin{array}{l}\text { Suman et al., 2018; Pajević } \\
\text { et al., 2016; Jabeen et al., } \\
2009\end{array}$ \\
\hline rhizofiltration & + & $+/-$ & $\mathrm{W}$ & $\begin{array}{l}\mathrm{Pb}, \mathrm{Cd}, \mathrm{Ni}, \mathrm{Cu}, \mathrm{Cr}, \mathrm{V} \\
\text { and radionuclides } \\
(\mathrm{U}, \mathrm{Cs}, \mathrm{Sr} \text { ) }\end{array}$ & $\begin{array}{l}\text { Tiwari et al., } 2019 \\
\text { Mikheev et al., 2017; Jabeen } \\
\text { et al., 2009; Dushenkov, } \\
2003\end{array}$ \\
\hline phytostabilisation & - & - & $\begin{array}{l}\text { S (high } \\
\text { OM) }\end{array}$ & $\begin{array}{l}\text { various wastes, } \\
\mathrm{HM}(\mathrm{Pb}, \mathrm{Zn}, \mathrm{Cu})\end{array}$ & $\begin{array}{l}\text { Clemente et al., 2019; } \\
\text { Barbosa and Fernando, } \\
\text { 2018; Jabeen et al., 2009 }\end{array}$ \\
\hline phytovolatilization & + & - & S, W & $\begin{array}{l}\text { Hg, Se, As, tritium, } \\
\text { chlorinated solvents, } \\
\text { methyl tert-butyl } \\
\text { ether (MTBE) }\end{array}$ & $\begin{array}{l}\text { Limmer and Burken, 2016; } \\
\text { Herath and Vithanage, } \\
\text { 2015; Jabeen et al., } 2009\end{array}$ \\
\hline phytodegradation & $+/-$ & - & S, W & $\begin{array}{l}\text { chlorinated solvents, } \\
\text { herbicides, } \\
\text { insecticides, } \\
\text { inorganic nutrients }\end{array}$ & $\begin{array}{l}\text { Chlebek and Hupert- } \\
\text { Kocurek, 2019; } \\
\text { Jabeen et al., } 2009\end{array}$ \\
\hline
\end{tabular}

† Note: (+) yes, (-) no

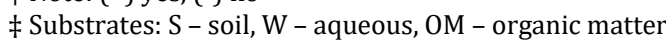

Although this green phytotechnology is known for over 50 years, phytoremediation has received increased attention in the last few years, reflected by the high number of papers published on the topic: more than 10 thousand in less than three decades (Zhang et al., 2020). However, the evidence for phytoremediation potential of plants from a given genus is scattered and this hinders a comprehensive view on phytoremediation importance at genus level, while also making the work difficult for specialists that prepare documentations for phytoremediation programs, particularly in choosing the most suitable species. Hence, this paper attempts to provide an outlook on genus Iris by gathering findings and reports related to the phytoremediation research conducted for these plants.

Genus Iris comprises over 200 herbaceous species (Tillie et al., 2000) with bulbs or rhizomes, that are native to northern hemisphere and reach high diversity in Eurasia. Irises present adaptation to a wide variety of habitats (Maynard, 1997). Iris plants have long been used as ornamental (Crișan et al., 2017), medicinal plants (Crișan and Cantor, 2016) or as source of dyes (Crișan et al., 2018) as well as metabolites with applications in cosmetic and food industry (Crișan et al., 2019). Given their ecologic versatility, these plants could be suitable candidates for phytoremediation across diverse conditions, especially considering the large number of species with various adaptations as well as vast number of cultivars grown throughout northern hemisphere, as well as worldwide where climatic conditions allows their cultivation.

Aim of this paper is to provide an overview on recent advances and insights related to the phytoremediation potential of plants from the genus Iris, in order to promote and extend the utilization of these species in phytoremediation programs.

The objectives of the review were to identify the species from genus Iris that present phytoremediation potential and highlight evidence for the type of pollutants irises might be effective against. 


\section{IRIS SPECIES FOR PHYTOREMEDIATION}

Literature screening revealed that Iris spp. phytoremediation capacity was studied during last ten years across nine European countries: Czechia, Denmark, France, Ireland, Poland, Portugal, Serbia, Slovakia, and Spain (Table 2). But at global level, a substantial contribution to this topic is brought by research from China (Table 3). Because irises have been used for many purposes in Eurasia across centuries (Crișan and Cantor, 2016), it is not surprising the fact that some countries actively involved in the research on phytoremediation potential of irises coincide with regions with a tradition in using these plants for various other purposes. In this case, the phytoremediation potential of these plants is adding one more application to their traditional importance.

Table 2. Relevant research from past decade in Europe on phytoremediation capacity of Iris spp.

\begin{tabular}{|c|c|c|c|c|}
\hline Type & Research focus & Iris species & Country & Source \\
\hline \multirow{9}{*}{$\sum_{\sum}^{\frac{n}{\pi}}$} & Effect of Cr stress on AMF inoculated plants & I. wilsonii & Czechia & Hu et al., 2020 \\
\hline & $\begin{array}{l}\text { Phytoaccumulation capacity and translocation of } \\
\mathrm{Zn} \text { and } \mathrm{Pb} \text { from rivers }\end{array}$ & I. pseudacorus & Poland & $\begin{array}{l}\text { Małachowska-Jutsz anc } \\
\text { Gumińska, } 2018\end{array}$ \\
\hline & $\begin{array}{l}\text { Bioaccumulation and translocation of } \mathrm{Pb}, \mathrm{Cd}, \mathrm{Hg} \text {, } \\
\text { As }\end{array}$ & I. pseudacorus & Serbia & Branković et al., 2018 \\
\hline & $\begin{array}{l}\text { Treatment of soil contaminated with } \mathrm{As}, \mathrm{Cd}, \mathrm{Cu} \\
\mathrm{Fe}, \mathrm{Pb} \text { and } \mathrm{Zn} \text { resulting from mining activities }\end{array}$ & I. pseudacorus & Spain & $\begin{array}{l}\text { Pérez-Sirvent et al., } \\
2016\end{array}$ \\
\hline & $\begin{array}{l}\text { Bioaccumulation capacity for } \mathrm{Zn}, \mathrm{Ni}, \mathrm{Fe}, \mathrm{Mn} \text { from } \\
\text { water and sediments }\end{array}$ & I. pseudacorus & Poland & Parzych et al., 2016 \\
\hline & $\begin{array}{l}\text { Bioaccumulation capacity for } \mathrm{Fe}, \mathrm{Pb}, \mathrm{Cd}, \mathrm{Cu}, \mathrm{Mn} \text {, } \\
\mathrm{Hg}, \mathrm{As}\end{array}$ & I. pseudacorus & Serbia & Branković et al., 2015 \\
\hline & $\begin{array}{l}\text { Adaptability of plant-endomycorrhiza under heavy } \\
\text { metal contamination }\end{array}$ & I. pseudacorus & Poland & Wężowicz et al., 2015 \\
\hline & $\begin{array}{l}\text { Influence of growth media contamination with } \mathrm{Cu} \\
\text { on root biomass }\end{array}$ & I. pseudacorus & France & Marchand et al., 2014 \\
\hline & Cr rhizo-filtration and $\mathrm{Zn}$ phytoextraction capacity & I. pseudacorus & Spain & Caldelas et al., 2012 \\
\hline \multirow{5}{*}{$\stackrel{\bar{\Xi}}{\bar{D}}$} & Furosemide removal from water & I. pseudacorus & Portugal & Machado et al., 2020 \\
\hline & Removal of imazalil and tebuconazole from water & I. pseudacorus & Denmark & Lv et al., 2016 \\
\hline & Removal of psychoactive compounds from water & I. pseudacorus & Slovakia & Mackul'ak et al., 2015 \\
\hline & Dissipation of polycyclic aromatic hydrocarbons & I. pseudacorus & France & Leroy et al., 2015 \\
\hline & Atrazine removal from water & I. pseudacorus & Poland & Marecik et al., 2012 \\
\hline \multirow{2}{*}{ 总 } & $\begin{array}{l}\text { Decontamination of industrial effluents with a } \\
\text { mixture of pollutants }\end{array}$ & I. pseudacorus & France & $\begin{array}{l}\text { Guittonny-Philippe et } \\
\text { al., } 2015\end{array}$ \\
\hline & Wastewater treatment (domestic effluent) & I. pseudacorus & Ireland & $\begin{array}{l}\text { O’Luanaigh and Gill, } \\
2012\end{array}$ \\
\hline
\end{tabular}

As for phytoremediation in general, a recent comprehensive review indicates that countries most actively involved in research on this topic are China, USA, India, Spain, and France but those most engaged in international cooperation in this domain are USA, France, Germany, Poland, and Australia (Zhang et al., 2020). It is expected that phytoremediation research in a given country overlaps with potential applications in respective geographic region and concerns plants that may successfully grow there. The advantage of using plants adapted at growing in the target area and having well-established cultivation technology, resides in higher success prospects of the phytoremediation initiative. Review of relevant research on phytoremediation potential of Iris spp. conducted in Europe during past decade, revealed that I. pseudacorus was by far the most common species used across studies, and to a lesser extent I. wilsonii (Table 2). To these species can be added several others that also present phytoremediation capacity according to research conducted worldwide, namely I. dichotoma, I. germanica, I. halophila, I. lactea, I. latifolia, I. sibirica (Table 3). It is noticeable that among Iris spp. used in these studies are found some of the most cultivated irises for ornamental purposes, such as I. pseudacorus, I. germanica, I. sibirica - easily recognizable through their distinctive flowers that bloom in spring (Figure 1).

Their widespread cultivation increases the relevance of research as it might guarantee successful applicability in most countries where these are already presently cultivated. Out of these three, I. pseudacorus naturally occurs in Europe and Asia and grows best in waterlogged habitats (White et al., 1997; Robu, 2005; RHS, 2021), making this plant a good option both for the phytoremediation of soil, sediments as well as water. This is most likely the reason why it is so frequently employed in phytoremediation studies since many of these are testing prototypes for water treatment technologies (Table 2). By contrast, I. germanica is native to Mediterranean region and is widespread garden plant that prefers a well-drained substrate with a neutral to alkaline pH (White et al., 1997; Robu, 2005; RHS, 2021), making this species potentially useful at phytoremediation of soils under such conditions. I. sibirica has a wide native distribution range from Northern Italy to Lake Baikal in Russia and has the advantage of growing also in acidic soil, but although prefers a moist substrate it does not tolerate a waterlogged environment like $I$. pseudacorus (White et al., 1997; Robu, 2005; RHS, 2021), fact that can limit somewhat the applicability of this 
species. Regarding the other Iris species mentioned in some studies, since these are less widespread in cultivation, first aspect to consider would be their adaptability to various conditions outside their natural range of distribution, as well as availability of sufficient planting material in the case of an actual phytoremediation program. Similarly, for the less known irises the prospective phytoremediation use depends on defining their specific requirements and cultivation technology, while species with narrower ecologic niche might be considered less viable due to limited application perspectives and potential acclimatization obstacles. The great advantage of using ornamentals in general and irises in particular for phytoremediation stays in the fact that these can be easily integrated in landscaping design schemes in urban and peri-urban environments.

Table 3. Latest insights into phytoremediation capacity of Iris spp. worldwide

\begin{tabular}{|c|c|c|c|c|}
\hline Type & Research focus & Iris species & Country & Source \\
\hline \multirow{9}{*}{ 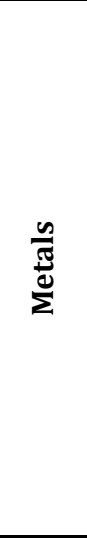 } & Effect of $\mathrm{Pb}$ on plant physiological parameters & I. germanica & China & Song et al., 2020 \\
\hline & Potential for $\mathrm{Zn}$ and $\mathrm{Cd}$ decontamination of soil & I. lactea & China & Hou et al., 2020 \\
\hline & $\mathrm{Pb}$ tolerance & I. lactea & China & Lu et al., 2020 \\
\hline & $\begin{array}{l}\text { Influence of Cd and } \mathrm{Zn} \text { concentration on } \\
\text { formation of iron plaque and on nutrient uptake }\end{array}$ & I. pseudacorus & China & Ma et al., 2020 \\
\hline & $\begin{array}{l}\text { Identification of proteins involved in Cd stress } \\
\text { response of plants }\end{array}$ & I. lactea & China & Liu et al., 2020 \\
\hline & $\mathrm{Ni}$ accumulation in plant organs & I. germanica & Pakistan & Sajad et al., 2020 \\
\hline & $\begin{array}{l}\text { Cd tolerance and accumulation for potential } \\
\text { treatment of contaminated paddy soils }\end{array}$ & I. sibirica & China & Wang et al., 2018 \\
\hline & $\begin{array}{l}\text { Assessing the influence of Pb contaminated } \\
\text { tailings exudate liquids on plant tolerance index } \\
\text { and translocation factor }\end{array}$ & I. pseudacorus & China & Yao, 2017 \\
\hline & $\mathrm{Pb}$ toxicity and uptake & I. halophila & China & Han et al., 2016 \\
\hline \multirow{5}{*}{ 总 } & Phosphate removal from water & I. latifolia & South Korea & Shabnam et al., 2019 \\
\hline & $\begin{array}{l}\text { Removal efficiency of } \mathrm{N} \text { from agricultural areas } \\
\text { to prevent water eutrophication }\end{array}$ & I. pseudacorus & China & Zhang et al., 2019 \\
\hline & $\begin{array}{l}\text { Removal of phosphate through a biorefinery } \\
\text { system }\end{array}$ & I. pseudacorus & Indonesia & Perdana et al., 2019 \\
\hline & Removal of $\mathrm{N}$ and $\mathrm{P}$ from water & $\begin{array}{l}\text { I. sibirica } \\
\text { I. pseudacorus }\end{array}$ & China & Yang et al., 2018 \\
\hline & $\begin{array}{l}\text { Removal of excessive nutrients (N, P) from fresh } \\
\text { and brackish eutrophic waters }\end{array}$ & I. pseudacorus & China & Zhao et al., 2015 \\
\hline \multirow{5}{*}{$\stackrel{\grave{d}}{\grave{\partial}}$} & $\begin{array}{l}\text { Treating polluted effluents resulting from } \\
\text { textile dyeing industry }\end{array}$ & I. pseudacorus & Indonesia & Tangahu et al., 2019 \\
\hline & $\begin{array}{l}\text { Effects of silver nanoparticles on removal of } \\
\text { pollutants and rhizosphere community } \\
\text { structure }\end{array}$ & I. pseudacorus & China & Huang et al., 2018 \\
\hline & $\begin{array}{l}\text { Evaluation of carbamazepine removal in a } \\
\text { wetland system }\end{array}$ & I. sibirica & Mexico & $\begin{array}{l}\text { Tejeda and Zurita, } \\
2020 ; \text { Tejeda et al., } \\
2017\end{array}$ \\
\hline & $\begin{array}{l}\text { Treating soil contaminated with petroleum } \\
\text { hydrocarbons }\end{array}$ & $\begin{array}{l}\text { I. dichotoma, } \\
\text { I. lactea }\end{array}$ & China & Cheng et al., 2017 \\
\hline & Remediation of petroleum contaminated soil & I. pseudacorus & China & Wang et al., 2016 \\
\hline
\end{tabular}

\section{IRIS SP. PLANT PARTS ACCUMULATING POLLUTANTS}

As observed from table 2, over a half of research from last decade that screened phytoremediation potential of Iris spp. in Europe focused on heavy metal/metalloids decontamination. However, when looking at the worldwide trend from last five years regarding phytoremediation potential of Iris spp., it can be observed that besides the studies concerned with heavy metal decontamination there is a growing interest for the potential of Iris plants to remove excess of nutrients besides petroleum hydrocarbons, dyes and pesticides (Table 3). Most likely in the following years more attention will be given to a larger array of pollutants and potential of these plants to mitigate them.

Accumulation of pollutants in plants depends on the concentration found in the growing environment, nature of the pollutant and plant-specific uptake capacity. Research has shown that I. pseudacorus plants accumulated higher levels of $\mathrm{Zn}, \mathrm{Fe}$ and $\mathrm{Mn}$ in roots compared to leaves while $\mathrm{Ni}$ reached higher levels in leaves compared to roots (Parzych et al., 2016). Similarly, Sajad et al. (2020) identified that I. germanica also accumulates higher levels of Ni in shoots $(249.36 \mathrm{mg} / \mathrm{kg})$ compared to roots $(84.00 \mathrm{mg} / \mathrm{kg})$. As for Pb, this element accumulated in higher levels in roots (up to $11156.7 \mathrm{mg} / \mathrm{kg}$ ) compared to shoots (up to $1077.5 \mathrm{mg} / \mathrm{kg}$ ) of I. lactea (Lu et al., 2020). Similar pattern 
was seen also in I. germanica (Song et al., 2020). For I. lactea var. chinensis the Cd concentration was higher in aboveground parts than in roots (Hou et al., 2020). This organ-specific accumulation can be attributed to the nature of the pollutant and its properties.

Experimental conditions are a first step in prospecting phytoremediation potential of a given plant species. But in order to determine the actual capacity of a plant to decontaminate, their performance has to be assessed in conditions that these could be eventually used.

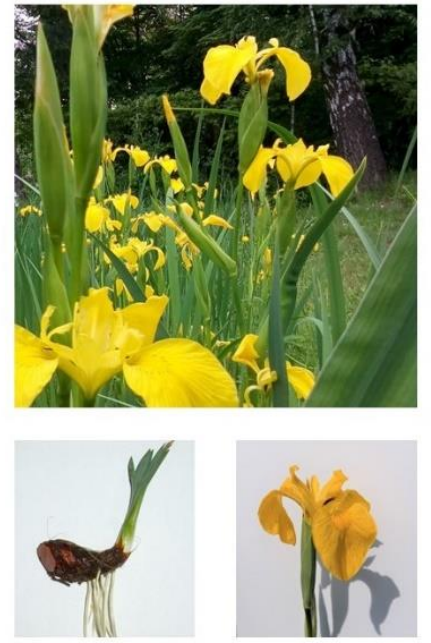

(a)
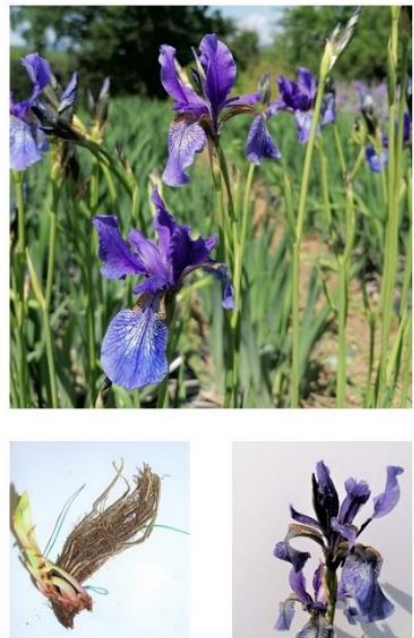

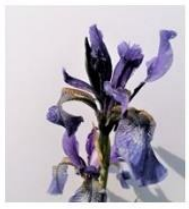

(b)
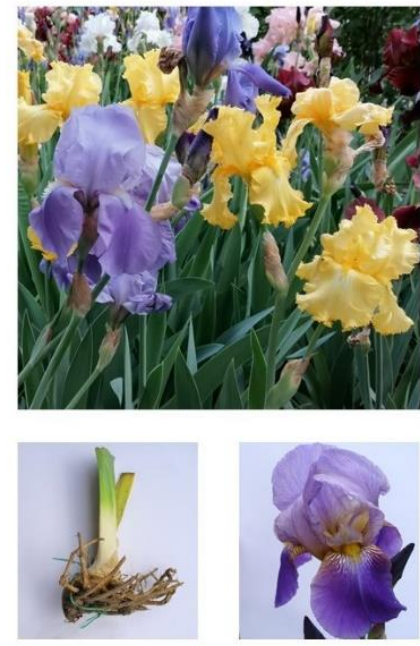

(c)

Figure 1. Some of the most cultivated Iris species: (a) I. pseudacorus; (b) I. sibirica; (c) I. germanica; rhizome and flower of each species (original).

The species I. germanica demonstrated phytoremediation capacity for some heavy metals following plant sampling from field as well as under experimental conditions. I. germanica plants collected in field from Lower Dir Pakistan demonstrated Ni bioconcentration factor of 9.87 and a translocation factor 2.97 (Sajad et al., 2020). Under experimental conditions, $\mathrm{Pb}$ level reached as high as $561.28 \mu \mathrm{g} / \mathrm{g}$ in roots of I. germanica under $1000 \mathrm{~Pb} \mathrm{mg} / \mathrm{kg}$ contamination. Both bioconcentration factor and translocation factor was higher at lower $\mathrm{Pb}$ concentration and decreased with the increasing concentration (Song et al., 2020) fact that suggests a reduction in decontamination efficiency with increased concentration of heavy metal.

Besides heavy metals pollution that pose a threat to the environment and human health, excess of nutrients from agriculture poses great concern because can lead to eutrophication of water bodies and cascading ecological degradation. Thus, identification of methods to mitigate excess of nutrients in environment is just as important. In regards with this aspect, a hydroponic experiment demonstrated that from a solution with a concentration of 9.6 $\mathrm{mg} / \mathrm{L}$ total nitrogen and $1.0 \mathrm{mg} / \mathrm{L}$ total phosphorus, the species I. pseudacorus and I. sibirica both ensured a removal rate of over $90 \%$ of total nitrogen and over $70 \%$ of total phosphorus in about one month (Yang et al., 2018).

In general, increased concentration of a contaminant usually negatively affects various growth parameters as observed for a series of plant species with phytoremediation ability (Capuana, 2020). In I. germanica increased Pb concentration was associated with significant decrease of plant height as well as number of leaves per plant besides other parameters (Song et al., 2020), proving that biomass is negatively affected by increased concentration of this pollutant. Increased concentration of pollutants also decreases efficiency of decontamination, as it was observed for I. pseudacorus that although showed high tolerance to total petroleum hydrocarbons the removal rate decreased at higher concentrations (Wang et al., 2016).

In order to alleviate the stress induced to plants by pollutants during phytoremediation and help plants cope with phyto-toxicity that negatively affects key physiological functions, association with beneficial rhizosphere micro-organisms might be a path worth exploring. Evidence emerged related to potential of arbuscular mycorrhizal fungi to successfully colonize roots of Iris spp. in waterlogged conditions and to exercise a protective role for plants as health and stability enhancer (Wężowicz et al., 2015; Hu et al., 2020). Such evidence is important considering that constructed wetlands are a highly efficient decontamination system and one of the most researched in phytoremediation literature (Herath and Vithanage, 2015). Optimization of phytoremediation might be possible through synergistic effect of endomycorrhiza-accumulator plant for successful decontamination, but more research is required to define the conditions and factors that intervene in the stability of this plant-microorganism interaction during remediation. 


\section{DECONTAMINATION AND CELL-LEVEL MECHANISMS IN IRIS SP.}

Common contaminants such as heavy metals, can lead to excessive production of reactive oxygen species that cause damage at cellular level and impairs cell metabolism (Han et al., 2016). Plants exhibit several mechanisms at cellular level that help them cope with heavy metal toxicity. Among these are binding metals to cell walls or to different ligands inside cells with the help of metallothioneins, phytochelatins and chaperones (Małachowska Jutsz and Gnida, 2015). Metal toxicity in plants can also be counteracted by the antioxidant system as well as accumulation of osmolytes that contribute to metal homeostasis. Studies on I. halophila showed that under $\mathrm{Pb}$ stress, activity of two key enzymes (superoxide dismutase and peroxidase), level of two soluble antioxidants (glutathione and ascorbic acid) as well as proline content were modulated in either underground or aerial plant parts in a dose-dependent manner, suggesting the importance these play for plant tolerance (Han et al., 2016). A proteomic approach enabled the identification of over 100 differentially expressed proteins in both shoots and roots of I. lactea under Cd stress (Liu et al., 2020) strongly indicating to a genetic control of plant response to heavy metal stress. Molecular manipulations with the goal of obtaining transgenic plants with enhanced phytoremediation ability are considered a viable possibility to optimize this green technology (Rai et al., 2020), and it will most likely be explored extensively in the future due to practical implications related to increased success rate of the phytoremediation process.

\section{USES OF CONTAMINATED IRIS SP. BIOMASS}

Handling and disposal of plant biomass resulting from phytoremediation poses further environmental concerns and safe valorization options of these contaminated organic materials are highly sought. The biomass valorization depends both on plant species used, type of pollutant and its concentration in plants (Vidican et al., 2020). Recent evidence emerged that I. sibirica Cobalt-rich biomass resulting from phytoremediation could be used in the domain of adsorption catalysis to remove $\mathrm{Hg}$ from coal combustion flue gas with highly promising industrial applications (Li et al., 2020; Wang et al., 2020). In this sense, results showed that after pyrolysis at $700^{\circ} \mathrm{C}, I_{\text {. sibirica biochar }}$ achieved Hg removal efficiency of 85\% (Wang et al., 2020). I. pseudacorus biomass resulting from biorefinery system used in removal of excess phosphate from water, could be valorized by obtaining flavonoid extract and compost. Results indicate that from $275 \mathrm{~kg}$ of I. pseudacorus biomass can result $57.6 \mathrm{~kg}$ of flavonoid powder (Perdana et al., 2019). Also, there might be other possibilities for the waste management of plant material from phytoremediation, as already tested for other species. Thus, activated carbon obtained from phytoremediation plant biomass could be used in wastewater treatment for efficient removal of dyes (Alshekhli et al., 2020).

Up-cycling possibilities for the contaminated biomass are relevant because they provide a valorization option for a plant material that otherwise represents a polluting waste. Sustainable processing channels for contaminated biomass can assist the decontamination process and might even cover some operational costs if proven feasible. However, in regards with Iris sp. such research is only at inception but constitutes a viable direction for the future. Designing an entire phytoremediation life cycle from phytoextraction to processing of removed biomass and secondary utilization options for derived biomass products might build the prototype for a sustainable chain. This could finally enable upscaling such a green technology and support the transitioning from experimental conditions towards more ambitious and larger scale initiatives.

\section{CONCLUSIONS}

Phytoremediation is a green technology that mitigates contamination from the environment using plants. Because Iris species are widely cultivated ornamentals presenting adaptation to a variety of habitats could be easily integrated in a phytoremediation landscaping scheme.

Research has shown that several Iris species have promising results regarding phytoremediation potential ( $I$. dichotoma, I. germanica, I. halophila, I. lactea, I. latifolia, I. pseudacorus, I. sibirica, I. wilsonii) against several toxic metals/metalloids as well as excess of nutrients from agriculture, pesticides, petroleum hydrocarbons, pharmaceuticals as well as dyes. The most researched species to date is I. pseudacorus because it can be used both for terrestrial as well as aquatic ecosystems.

Recent evidence emerged that contaminated Iris spp. biomass resulting from the phytoremediation process could find some applications, but upcycling possibilities depend on the contaminant type. The knowledge on this aspect is limited and can be considered a hindrance in upscaling this green method. Thus, entire cycle models that include phytoremediation-biomass harvest-secondary valorization are the most important areas that should be researched in the future in order to make this technology feasible and implementable at larger scale.

Author Contributions: I.C. conceived and wrote the paper; R.V., A.P. and T.M. edited and revised the paper. 
Funding Source: This work was supported by SPIRE - Smart Post-Industrial Regenerative Ecosystem Baia Mare (Project UIA04-138). This project is co-financed by the European Regional and Development Fund through the Urban Innovative Actions Initiative.

\section{Conflicts of Interest}

The authors declare that they do not have any conflict of interest.

\section{REFERENCES}

1. Ali H, Khan E, Sajad MA (2013) Phytoremediation of heavy metals-Concepts and applications. Chemosphere; 91: 869-881.

2. Alshekhli AF, Hasan HA, Muhamad MH, Abdullah SRS (2020) Journal of Ecological Engineering; 21(8): 207-215.

3. Ansari AA, Gill SS, Gill R, Lanza GR, Newman L (2017) Phytoremediation: Management of environmental contaminants. Volume 5. Cham: Springer.

4. Barbosa B, Fernando AL (2018) Aided phytostabilization of mine waste. In: Prasad MNV, Campos FPJ, Maiti SK, editors. Bio-geotechnologies for mine site rehabilitation. Elsevier; p. 147-157.

5. Branković $\mathrm{S}$, Glišić R, Topuzović M, Đekić V, Marin M (2018) The bioaccumulation and translocation potential of some aquatic plants. Water Research and Management; 8(2): 17-23.

6. Branković S, Glišić R, Topuzović M, Marin M (2015) Uptake of seven metals by two macrophytes species: potential for phytoaccumulation and phytoremediation. Chemistry and Ecology; 31(7): 583-593.

7. Caldelas C, Araus JL, Febrero A, Bort J (2012) Accumulation and toxic effects of chromium and zinc in Iris pseudacorus L. Acta Physiologiae Plantarum; 34(3): 1217-1228.

8. Capuana M (2020) A review of the performance of woody and herbaceous ornamental plants for phytoremediation in urban areas. iForest; 13: 139-151.

9. Cheng L, Wang Y, Cai Z, Liu J, Yu B, Zhou Q (2017) Phytoremediation of petroleum hydrocarbon-contaminated saline-alkali soil by wild ornamental Iridaceae species. International Journal of Phytoremediation; 19(3): 300308.

10. Chlebek D, Hupert-Kocurek K (2019) Endophytic bacteria in the phytodegradation of persistent organic pollutants. Postepy Mikrobiologii; 58(1): 70-79.

11. Clemente R, Arco-Lázaro E, Pardo T, Martín I, Sánchez-Guerrero A, Sevilla F, et al. (2019) Combination of soil organic and inorganic amendments helps plants overcome trace element induced oxidative stress and allows phytostabilisation. Chemosphere; 223: 223-231.

12. Crișan I, Cantor M (2016) New perspectives on medicinal properties and uses of Iris sp. Hop and Medicinal Plants; 24 (1-2): 24-31.

13. Crișan I, Vidican R, Borsai O, Stoie A, Stoian V (2017) Herbaceous companion plants for iris in Cluj county. ProEnvironment; 10: 238-244.

14. Crişan I, Vidican R, Morea A, Simea Ş (2018) Dyeing potential of linen fabric with Iris flower extracts. ProEnvironment; 11: 223-227.

15. Crișan I, Vidican R, Olar L, Stoian V, Morea A, Ștefan R (2019) Screening for changes on Iris germanica L. rhizomes following inoculation with arbuscular mycorrhiza using Fourier Transform Infrared Spectroscopy. Agronomy; 9(12): 815.

16. Dushenkov S (2003) Trends in phytoremediation of radionuclides. Plant and Soil; 249: 167-175.

17. EEA, Soil contamination widespread in Europe, [Internet], Last Accessed on 26/09/2020, Available from https://www.eea.europa.eu/highlights/soil-contamination-widespread-in-europe

18. Guittonny-Philippe A, Petit ME, Masotti V, Monnier Y, Malleret L, Coulomb B, et al. (2015) Selection of wild macrophytes for use in constructed wetlands for phytoremediation of contaminant mixtures. Journal of Environmental Management; 147: 108-123.

19. Han Y, Zhang L, Yang Y, Yuan H, Zhao J, Gu J, et al. (2016) Pb uptake and toxicity to Iris halophila tested on Pb mine tailing materials. Environmental Pollution; 214: 510-516.

20. Herath I, Vithanage M (2015) Phytoremediation in constructed wetlands. In: Ansari AA et al., editors. Phytoremediation: Management of environmental contaminants. Volume 2. Springer.

21. Hou X, Teng W, Hu Y, Yang Z, Li C, Scullion J, et al. (2020) Potential phytoremediation of soil Cadmium and Zinc by diverse ornamental and energy grasses. BioResources; 15(1): 616-640. 
22. Hu S, Bo H, Chen Z, Vosátka M, Vymazal J (2020) Antioxidant response in arbuscular mycorrhizal fungi inoculated wetland plant under Cr stress. Environmental Research; 191: 110203.

23. Huang J, Cao C, Yan C, Guan W, Liu J (2018) Comparison of Iris pseudacorus wetland systems with unplanted systems on pollutant removal and microbial community under nanosilver exposure. Science of The Total Environment; 624: 1336-1347.

24. Jabeen R, Ahmad A, Iqbal M (2009) Phytoremediation of heavy metals: physiological and molecular mechanisms. Botanical Review; 75: 339-364.

25. Leroy MC, Legras M, Marcotte S, Moncond'huy V, Machour N, Le Derf F, et al. (2015) Assessment of PAH dissipation processes in large-scale outdoor mesocosms simulating vegetated road-side swales. Science of The Total Environment; 520: 146-153.

26. Li H, Zhang J, Cao Y, Liu C, Li F, Song Y, et al. (2020) Role of acid gases in Hg0 removal from flue gas over a novel cobalt-containing biochar prepared from harvested cobalt-enriched phytoremediation plant. Fuel Processing Technology; 207: 106478.

27. Limmer M, Burken J (2016) Phytovolatilization of organic contaminants. Environmental Science \& Technology; 50(13): 6632-6643.

28. Liu Q, Zhang Y, Wang Y, Wang W, Gu C, Huang S, et al. (2020) Quantitative proteomic analysis reveals complex regulatory and metabolic response of Iris lactea Pall. var. chinensis to cadmium toxicity. Journal of Hazardous Materials; 400(5): 123165.

29. Lu W, Li Z, Shao Z, Zheng C, Zou H, Zhang J (2020) Lead tolerance and enrichment characteristics of several ornamentals under hydroponic culture. Bulletin of Environmental Contamination and Toxicology; 105: 166172.

30. Lv T, Zhang Y, Zhang L, Carvalho PN, Arias CA, Brix H (2016) Removal of the pesticides imazalil and tebuconazole in saturated constructed wetland mesocosms. Water Research; 91: 126-136.

31. Ma H, Gao F, Zhang X, Cui B, Liu Y, Li Z (2020) Formation of iron plaque on roots of Iris pseudacorus and its consequence for cadmium immobilization is impacted by zinc concentration. Ecotoxicology and Environmental Safety; 193: 110306.

32. Machado AI, Fragoso R, Dordio AV, Duarte E (2020) Performance of Iris pseudacorus and Typha domingensis for furosemide removal in a hydroponic system. International Journal of Phytoremediation; 22(8): 863-871.

33. Mackul'ak T, Mosný M, Škubák J, Grabic R, Birošová L (2015) Fate of psychoactive compounds in wastewater treatment plant and the possibility of their degradation using aquatic plants. Environmental Toxicology and Pharmacology; 39(2): 969-973.

34. Małachowska-Jutsz A, Gnida A (2015) Mechanisms of stress avoidance and tolerance by plants used in phytoremediation of heavy metals. Archives of Environmental Protection; 41(4): 104-114.

35. Małachowska-Jutsz A, Gumińska J (2018) Zinc and lead in aquatic plants and bottom sediments of anthropogenic rivers. The Silesian University of Technology, Architecture Civil Engineering Environment; 2: 125-134.

36. Marchand L, Nsanganwimana F, Lamy JB, Quintela-Sabaris C, Gonnelli C, Colzi I, et al. (2014) Root biomass production in populations of six rooted macrophytes in response to $\mathrm{Cu}$ exposure: Intra-specific variability versus constitutive-like tolerance. Environmental Pollution; 193: 205-215.

37. Marecik R, Białas W, Cyplik P, Ławniczak $€$, Chrzanowski $€$ (2012) Phytoremediation potential of three wetland plant species toward atrazine in environmentally relevant concentrations. Polish Journal of Environmental Studies; 21(3): 697-702.

38. Maynard P (1997) Cultivation and the great genus In: White et al., editors. A guide to species irises: their identification and cultivation edited by British Iris Society Species Group. Cambridge University Press.

39. Mikheev AN, Lapan OV, Madzhd SM (2017) Experimental foundations of a new method for rhizofiltration treatment of aqueous ecosystems from 137Cs. Water Treatment and Demineralization Technology; 39: 245249.

40. O'Luanaigh N, Gill LW (2012) The attenuation capacity of constructed wetlands to treat domestic wastewater in Ireland. International Symposium on Domestic Wastewater Treatment \& Disposal Systems: Trinity College; September 10-11; Dublin, Ireland.

41. Pajević S, Borišev M, Nikolić N, Arsenov DD, Orlović S, Župunski M (2016) Phytoextraction of heavy metals by fast-growing trees: a review. In: Ansari A, Gill S, Gill R, Lanza G, Newman L, editors. Phytoremediation. Cham: Springer; p. 29-64. 
42. Parzych A, Cymer M, Macheta K (2016) Leaves and roots of Typha latifolia L. and Iris pseudacorus L. as bioindicators of contamination of bottom sediments by heavy metals. Limnological Review; 16(2): 77-83.

43. Perdana MP, Rifqi HD, Muhammad IH (2019) Preliminary design for phytoremediation of phosphate from liquid fertilizer waste by duckweed (Spirodela sp.) and yellow iris (Iris pseudacorus L.) integrated with biorefinerybased processing system to produce value-added bioproducts. UI Proceedings on Science and Technology, 2: 61-66.

44. Pérez-Sirvent C, Hernandez Perez C, Sanchez M, Jose M, García LM, Hernandez-Cordoba M, et al. (2016) Usefulness of phytoremediation in sites with high levels of potentially toxic elements: results for a case study. EGU General Assembly; April 17-22; Vienna: Austria, id. EPSC2016-18045.

45. Rai PK, Ki-Hyun K, Sang SL, Leed JH (2020) Molecular mechanisms in phytoremediation of environmental contaminants and prospects of engineered transgenic plants/microbes. Science of the Total Environment; 705: 135858.

46. RHS, Royal Horticultural Society - plants: I. pseudacorus, I. germnaica, I. sibirica, [Internet], Last Accessed on 02/03/2021, Available from https://www.rhs.org.uk

47. Robu T (2005) Monography of the genus Iris: physiology, botany and uses. "Ion Ionescu de la Brad" Publishing House. Iași: Romania.

48. Sajad MA, Khan MS, Bahadur S, Shuaib M, Naeem A, Zaman W, et al. (2020) Nickel phytoremediation potential of some plant species of the Lower Dir, Khyber Pakhtunkhwa, Pakistan. Limnological Review; 20(1): 13-22.

49. Shabnam N, Ahn Y, Maksachev A, Lee JH, Huang CP, Kim H (2019) Application of red-mud based ceramic media for phosphate uptake from water and evaluation of their effects on growth of Iris latifolia seedling. Science of The Total Environment; 688: 724-731.

50. Song X, Zhang C, Chen W, Zhu Y, Wang Y (2020) Growth responses and physiological and biochemical changes in five ornamental plants grown in urban lead-contaminated soils. Plant-Environment Interactions; 1(1): 2947.

51. Suman J, Uhlik 0, Viktorova J, Macek T (2018) Phytoextraction of heavy metals: a promising tool for clean-up of polluted environment? Frontiers in Plant Science; 9: 1476.

52. Surriya O, Sayeda SS, Waqar K, Gul KA (2015) Phytoremediation of soils: prospects and challenges. In: Hakeem KR, Sabir M, Öztürk M, Mermut AR, editors. Soil remediation and plants. Academic Press.

53. Tangahu BV, Dwi AN, Setyo BK, Muhammad FI (2019) Study of BOD and COD removal in Batik wastewater using Scirpus grossus and Iris pseudacorus with Intermittent Exposure System. Journal of Ecological Engineering; 20(5): 130-134.

54. Tejeda A, Torres-Bojorges ÁX, Zurita F (2017) Carbamazepine removal in three pilot-scale hybrid wetlands planted with ornamental species. Ecological Engineering; 98: 410-417.

55. Tejeda A, Zurita F (2020) Capacity of two ornamental species (Iris sibirica and Zantedeschia aethiopica) to take up, translocate, and accumulate carbamazepine under hydroponic conditions. Water; 12: 1272.

56. Tillie N, Chase MW, Hall T (2000) Molecular studies in the genus Iris L.: A preliminary study. Annali di Botanica; 58: 105-112.

57. Tiwari J, Sweta A, Sanjeev K, Korstad J, Bauddh K (2019) Ecorestoration of polluted aquatic ecosystems through rhizofiltration. In: Pandey VC and Bauddh K, editors. Phytomanagement of polluted sites market opportunities in sustainable phytoremediation. Elsevier; p. 179-201.

58. Vidican R, Mihăiescu T, Pleşa A, Crişan I (2020) Opportunities for the utilization of phytoremediation biomass rich in heavy metals. ProEnvironment; 13(43): 77-81.

59. Wang Y, Li H, He Z, Guan J, Qian K, Hu J (2020) Removal of elemental mercury from flue gas using cobaltcontaining biomaterial carbon prepared from contaminated Iris sibirica biomass. ACS Omega; 5(12): 62886298.

60. Wang Y, Lv N, Mao X, Yan Z, Wang J, Tan W, et al. (2018) Cadmium tolerance and accumulation characteristics of wetland emergent plants under hydroponic conditions. RSC Advances; 8: 33383-90.

61. Wang YN, Cheng LJ, Zhou QX (2016) Phytoremediation of petroleum contaminated soils with Iris pseudacorus L. and the metabolic analysis in roots. Huan Jing Ke Xue; 37(4):1531-8.

62. Wężowicz K, Turnau K, Anielska T, Zhebrak I, Gołuszka K, Błaszkowski J, et al. (2015) Metal toxicity differently affects the Iris pseudacorus-arbuscular mycorrhiza fungi symbiosis in terrestrial and semi-aquatic habitat. Environmental Science and Pollution Research; 22: 19400-19407.

63. White B, Bowley M, Brearley C, Christiansen H, Cohen O, Davis AP, et al. (1997) A guide to species irises: their identification and cultivation edited by British Iris Society Species Group. Cambridge University Press. 
64. Yang J, Qi Y, Li H, Xu G (2018) Comparison of nitrogen and phosphorus purification effects of different wetland plants on eutrophic water. ICAESEE IOP Conf. Series: Earth and Environmental Science; 113: 012042.

65. Yao N (2017) Research on Iris pseudacorus and Sagittaria sagittifolia's accumulation ability on $\mathrm{Pb}$ tailings exudated liquids. $2^{\text {nd }}$ International Conference on Materials Engineering and Information Technology Applications (MEITA), Advances in Engineering Research; 107: 192-196.

66. Zhang X, Zha L, Jiang P, Wang X, Lu K, He S, et al. (2019) Comparative study on nitrogen removal and functional genes response between surface flow constructed wetland and floating treatment wetland planted with Iris pseudacorus. Environmental Science and Pollution Research; 26(23): 23696-23706.

67. Zhang Y, Li C, Ji X, Yun C, Wang M, Luo X (2020) The knowledge domain and emerging trends in phytoremediation: a scientometric analysis with CiteSpace. Environmental Science and Pollution Research; 27: 15515-15536.

68. Zhao H, Wang F, Ji M (2015) Brackish eutrophic water treatment by Iris pseudacorus L.-planted microcosms: physiological responses of Iris pseudacorus L. to salinity. International Journal of Phytoremediation; 17(9): 81421. 